JURNAL KESEHATAN PENA MEDIKA VOL 9 (2) DESEMBER 2019

PENA MEDIKA

FAKULTAS ILMU KESEHATAN UNIVERSITAS PEKALONGAN

http://jurnal.unikal.ac.id/index.php/medika ISSN : 2086-843X

\title{
STUDI PENINJAUAN KUALITAS MINYAK GORENG HASIL PEMANASAN BERDASARKAN PADA BILANGAN PENYABUNAN
}

\author{
Siska Rusmalina ${ }^{1)}$ \\ Program Studi D III Farmasi \\ Fakultas Farmasi, Universitas Pekalongan \\ Email: siska_wibowoapt@yahoo.co.id
}

\begin{abstract}
ARTICLE INFO :
Accepted

Approve

Publish
\end{abstract}

\begin{abstract}
ABSTRAK
Minyak goreng termasuk dalam 9 bahan pokok makanan yang dibutuhkan oleh masyarakat sehingga tingkat kebutuhan minyak goreng sangat tinggi. Minyak goreng dapat mengalami kerusakan akibat reaksi oksidasi dari suatu pemanasan. Salah satu pemicu terjadinya reaksi oksidasi adalah pemanasan. Minyak yang dipanaskan akan turun kualitasnya atau bahkan menjadi rusak. Masyarakat banyak menggunakan minyak goreng dengan lama pemanasan yang tidak lama dan digunakan secara berulang. Hal ini akan mempengaruhi kualitas dari minyak goreng tersebut. Minyak goreng dengan kualitas jelek, apabila dikonsumsi dapat menimbulkan penyakit hipertensi, jantung, dan stroke. Penentuan kualitas minyak dapat dilakukan dengan mengukur bilangan penyabunan yang terdapat pada sampel minyak goreng. Tujuan penelitian ini yaitu mengetahui hubungan lama pemanasan terhadap kualitas minyak goreng yang ditinjau dari bilangan penyabunan.

Sampel yang digunakan adalah minyak goreng curah yang banyak dikonsumsi oleh konsumen dan dari produsen yang berbeda di Kota Pekalongan. Pengambilan sampel menggunakan metode purposive sampling. Pengujian ini mengacu pada syarat mutu minyak goreng berdasarkan SNI 7431 : 2015. Angka penyabunan pada minyak goreng sesuai SNI 7431 : 2015 adalah 180 - 265 mg kOH/g. Penetapan angka bilangan penyabunan digunakan metode titrasi asidi alkalimetri.

Hasil pengujian bilangan penyabunan pada kelima sampel yaitu $183.2-240.22 \mathrm{mg} \mathrm{NaOH} / \mathrm{gram}$. Hasil tersebut tidak melebihi batas standar yang ditetapkan oleh SNI 7431 : 2015 yaitu 180 - 265 mg. Namun jika dilihat dari parameter lama pemanasan seluruh sampel mengalami kenaikan bilangan penyabunan pada tiap kenaikan lama pemanasan. Dengan demikian dapat disimpulkan bahwa semakin lama minyak goreng dipanaskan, maka akan semakin besar pula tingkat kerusakan dan penurunan kualitas dari minyak goreng tersebut.
\end{abstract}

Keywords: Kualitas, Minyak Goreng, Lama Pemanasan, Bilangan Penyabunan 


\section{ABSTRACT}

Cooking oil is included in 9 food staples needed by the community so that the level of cooking oil needs is very high. Cooking oil can be damaged due to the oxidation reaction of a heating. One of the triggers of an oxidation reaction is heating. Heated oil will drop in quality or even become damaged. Many people use cooking oil with a long heating time and is used repeatedly. This will affect the quality of the cooking oil. Cooking oil with low quality, if consumed can cause hypertension, heart disease, and stroke. Determination of oil quality can be done by measuring the saponification numbers contained in cooking oil samples. The purpose of this study was to determine the relationship of heating time to the quality of cooking oil in terms of the saponification numbers.

The sample used is bulk cooking oil which is widely consumed by consumers and from different producers in Pekalongan City. Sampling using a purposive sampling method. This test refers to the quality requirements for cooking oil based on SNI 7431: 2015. The saponification value of cooking oil according to SNI 7431: 2015 is 180-265 mg kOH / g. Determination of the saponification numbers is used asidi alkalimetri titration method.

The results of the saponification numbers in the five samples are $183.2-240.22 \mathrm{mg} \mathrm{NaOH} / \mathrm{gram}$. These results do not exceed the standard limits set by SNI 7431: 2015 which is 180-265 mg. However, if seen from the parameters of heating duration, all samples have increased the saponification number for each increase in heating time. It can be concluded that the longer the cooking oil is heated, the greater the level of damage and deterioration in the quality of the cooking oil.

Keywords: Kualitas, Minyak Goreng, Lama Pemanasan, Bilangan Penyabunan 


\section{PENDAHULUAN}

Di Indonesia minyak goreng termasuk dalam 9 bahan pokok masyarakat Indonesia. Data Nutrition Foundation For Food Fortification pada tahun 2014 menyatakan bahwa jumlah kebutuhan minyak goreng di Dunia mencapai 3,2 M/T per tahun. Data tersebut menunjukkan bahwa tidak dapat dipungkiri lagi tingginya tingkat konsumsi minyak goreng oleh masyarakat.

Minyak goreng yang digunakan pada saat penggorengan akan mengalami proses okidasi. Proses ini akan semakin paras jika digoreng dalam waktu yang. Hal ini disebabkan adanya korelasi antara lama pemanasan dengan tingginya tingkat kerusakan yang terjadi pada minyak goreng. Proses oksidasi pada minyak goreng ditandai dengan adanya pembentukan peroksida dan hidroperoksida yang menimbulkan bau tengik, dan terjadi perubahan struktur kimia pada minyak goreng yang mengakibatkan minyak tersebut rusak atau kualitasnya menjadi jelek sehingga tidak dianjurkan untuk dikonsumsi. Seseorang yang mengkonsumsi minyak yang telah mengalami oksidasi atau kerusakan dapat menyebabkan kelambatan pertumbuhan, pembesaran organ, kanker, kontrol tidak sempurna pada pusat syaraf dan mempersingkat umur (Ketaren, 2008).

Kebanyakan konsumen tidak mengetahui dan tidak menyadari bahwa kualitas minyak goreng yang buruk dapat menyebabkan berbagai penyakit seperti meningkatnya kadar Low Desinty Lipoprotein (LDL) dalam darah yang dapat menyebabkan penyakit jantung koroner, kardiovaskular, hipertensi dan kanker (Winarno, 1999).

Kerusakan pada suatu minyak berkorelasi dengan kualitas minyak. Penentuan kualitas minyak dapat dilakukan pengan menghitung bilangan penyabunan yang ada pada minyak. Bilangan penyabunan pada minyak dalam satuan milligram menurut Standar Nasional Indonesia (SNI) $7431: 2015$ minimal bernilai 180-265 mg KOH/gram (SNI, 2015).

Penelitian Oktaviani, N.D., 2009. Menunjukkan bahwa terdapat hubungan yang signifikan antara lama pemanasan dengan bilangan peroksida.

Dengan demikian perlunya dilakukan studi kualitas minyak goreng setelah pemanasan berdasarkan pada penentuan nilai bilangan penyabunan. 


\section{METODE}

Penelitian ini merupakan penelitian eksperimental Kuasi. variabel bebas yaitu lamanya pemanasan. Penelitian ini dilakukan untuk mengungkapkan hubungan sebab akibat tiga variabel yaitu lama pemanasan dengan bilangan penyabunan dengan mengendalikan variabel lain yaitu suhu pemanasan. Pemanasan minyak goreng akan dilakukan dengan interval waktu 0,10 , 30, 40, 50 dan 60 menit.

Pengambilan sampel dilakukan diwilayah Pekalongan pada bulan JuniAgustus 2018. Adapun tempat pengujian sampel dilakukan di laboratorium kimia Universitas Pekalongan.

Alat dan Bahan:

Alat yang digunakan Alat yang digunakan dalam penelitian yaitu neraca analitik (shimadzu), labu erlemeyer 250 $\mathrm{mL}$ (pyrex), pipet tetes, pipet volume 10 $\mathrm{mL}$ (pyrex), labu takar $100 \mathrm{~mL}$ (pyrex), filler, beaker glass $1000 \mathrm{~mL}$ (pyrex), beaker glass $50 \mathrm{~mL}$ (pyrex), sendok tanduk, kaca arloji, gelas ukur $50 \mathrm{~mL}$ (pyrex), termometer kimia, satu set peralatan refluks, pembakar bunsen, statif dan klem, kertas perkamen, batang pengaduk, buret $50 \mathrm{~mL}$ (pyrex), dan kain lap.

Bahan yang digunakan dalam penelitian ini adalah sampel minyak goreng curah, etanol 95\% (Brataco), indicator phenopthlain (Brataco), indikator metil orange, $\mathrm{NaOH} 0,1 \mathrm{~N}$ (Brataco), $\mathrm{HCl}$ standar $0,5 \mathrm{~N}$ (Brataco), $\mathrm{Na}_{2} \mathrm{~B}_{4} \mathrm{O}_{7} 0,5 \mathrm{~N}$ (Brataco), aquadest, alumunium foil, dan kertas saring.

Cara keja:

a. Pemanasan Sampel

1. Panaskan sampel minyak goreng pada wajan pemanasan.

2. Ambil sampel yang dipanaskan pada interval waktu $0,10,30,40$, 50 dan 60 menit.

b. Penentuan Bilangan Penyabunan (BSN, 2015)

1. Sampel uji hasil pemanasan ditimbang $5 \mathrm{~g}$ dimasukkan dalam erlenmayer $250 \mathrm{~mL}$.

2. Tambahkan 50,0 mL larutan $\mathrm{NaOH}$ dalam etanol $70 \%$, dan beberapa tetes indikator $\mathrm{pp}$.

3. Erlenmayer ditutup dengan pendingin balik (kondensor), dipanaskan dengan hati-hati selama 30 menit (larutan harus berwarna merah).

4. Titrasi kelebihan $\mathrm{NaOH}$ dengan 
larutan $\mathrm{HCl}$ standar 0,5 N sampai terjadi perubahan warna dari merah menjadi tidak berwarna.

5. Titrasi blanko dengan cara yang sama pada titrasi sampel dengan terlebih dahulu dilakukan pemanasan pada kondensor

6. Dicatat volume titrannya.

7. Dihitung bilangan penyabunannya

8. Dilakukan replikasi sebanyak 3 kali

c. Standarisasi $\mathrm{Na}_{2} \mathrm{~B}_{4} \mathrm{O}_{7} 0,5 \mathrm{~N}$ dengan $\mathrm{HCl}$.

1. Dipipet $\quad 10,0 \quad \mathrm{~mL} \quad \mathrm{Na}_{2} \mathrm{~B}_{4} \mathrm{O}_{7}$, dimasukan dalam erlemayer

2. Ditambahkan $40 \mathrm{~mL}$ aquadest dan 2 tetes indikator pp $1 \%$.

3. Dititrasi dengan larutan $\mathrm{HCl}$ standart sampai terjadi warna merah muda konstan, dan cata volume $\mathrm{HCl}$.

\section{HASIL DAN PEMBAHASAN}

Penelitian ini dilakukan untuk mengetahui hubungan lama pemanasan. Pemanasan yang terlalu lama akan mengakibatkan kerusakan fisik dan kimia pada minyak dengan terjadinya ikatan tak jenuh dapat teroksidasi menghasilkan pembentukan gugus karbonil yang pada akhirnya bereaksi dengan alkali sehingga terjadi reaksi hidrolisis penyabunan. Reaksi kimia yang terjadi sebagai berikut:

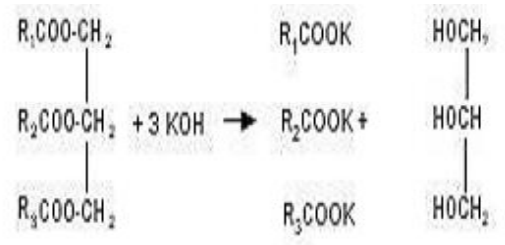

\section{Gamabar 1. Reaksi Penyabunan Minyak}

Penentuan bilangan penyabunan merupakan jumlah milligram $\mathrm{KOH}$ yang diperlukan untuk menyabunkan satu gram minyak atau lemak (Winarno, 1991), Nilai bilangan penyabunan yang diperoleh pada penelitian ini sebagai menunjukkan jumlah asam lemak tak jenuh yang terkandung dalam minyak goreng, sebagai indikator kualitas minyak.

Pemanasan pada minyak akan mengakibatkan terbentuknya asam lemak tak jenuh. Semakin lama pemanasan tentu saja akan meningkat jumah asam lemak tak jenuh yang ada pada minyak goreng. Hal ini akan sebanding dengan kualitias dari minyak goreng.

Sampel minyak goreng pada penelitian ini berjumlah 5 sampel minyak goreng curah yang berasal dari distributor yang 
berbeda. Hasil penentuan bilangan penyabunan terdapat pada tabel I.

Data pada tabel I, memperlihatkan bahwa bilangan penyabunan seluruh sampel berada pada rentang 183.2 $240.22^{\mathrm{NaOH} / g r a m}$. Dengan nilai rata-rata $189,28-214,55^{\mathrm{NaOH} / \text { gram. }}$ Hasil tersebut tidak melebihi batas standar

Tabel 1. Hasil penentuan bilangan penyabunan sampel

\begin{tabular}{|c|c|c|c|c|c|c|c|c|}
\hline \multirow{2}{*}{$\begin{array}{c}\text { Lama } \\
\text { pemanasan } \\
\text { (menit) }\end{array}$} & \multicolumn{8}{|c|}{$\begin{array}{c}\text { Sampel } \\
\text { (mg NaOH/gram) }\end{array}$} \\
\hline & I & II & III & IV & V & $\begin{array}{l}\text { Rata- } \\
\text { Rata }\end{array}$ & SD & RSD \\
\hline 0 & 183.2 & 190.29 & 194.26 & 187.26 & 191.38 & 189.278 & 4.221294 & 2.230208 \\
\hline 10 & 184.14 & 193.36 & 197.34 & 190.45 & 193.23 & 191.704 & 4.889328 & 2.550457 \\
\hline 30 & 194.81 & 197.54 & 197.61 & 199.98 & 197.67 & 197.522 & 1.832122 & 0.927553 \\
\hline 40 & 195.54 & 208.3 & 197.65 & 210 & 198.71 & 202.04 & 6.617405 & 3.275295 \\
\hline 50 & 197.64 & 210.5 & 201.55 & 226.18 & 199.99 & 207.172 & 11.68789 & 5.641634 \\
\hline 60 & 205.8 & 220.67 & 230.97 & 240.22 & 224.12 & 224.356 & 12.78064 & 5.696589 \\
\hline
\end{tabular}

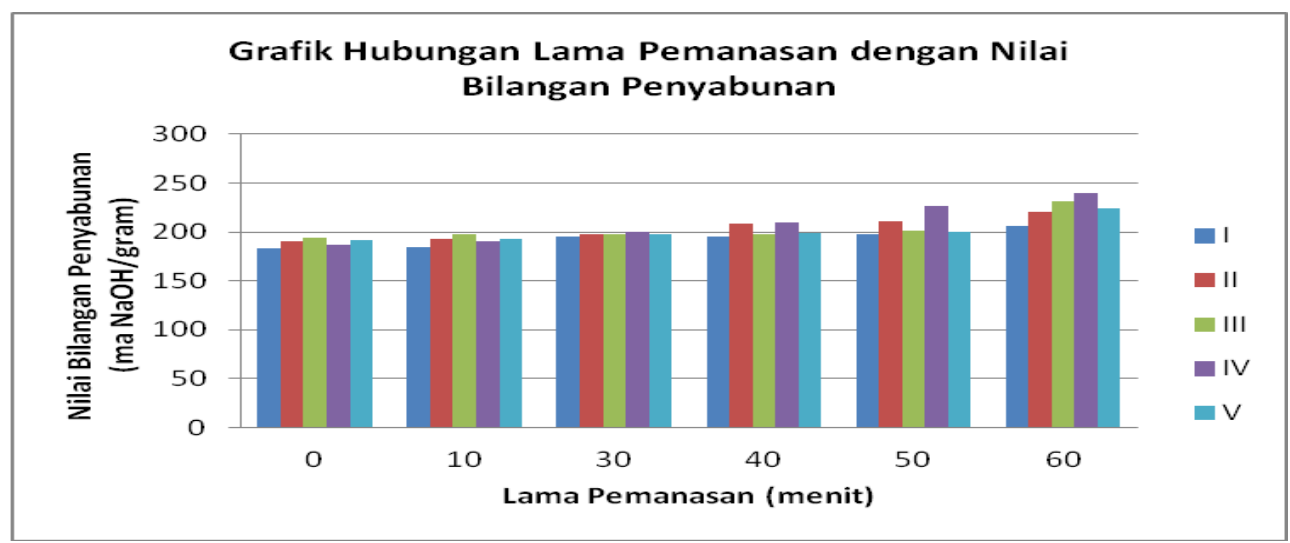

Gambar 2. Grafik Hubungan Lama Pemanasan dengan Bilangan Penyabunan 


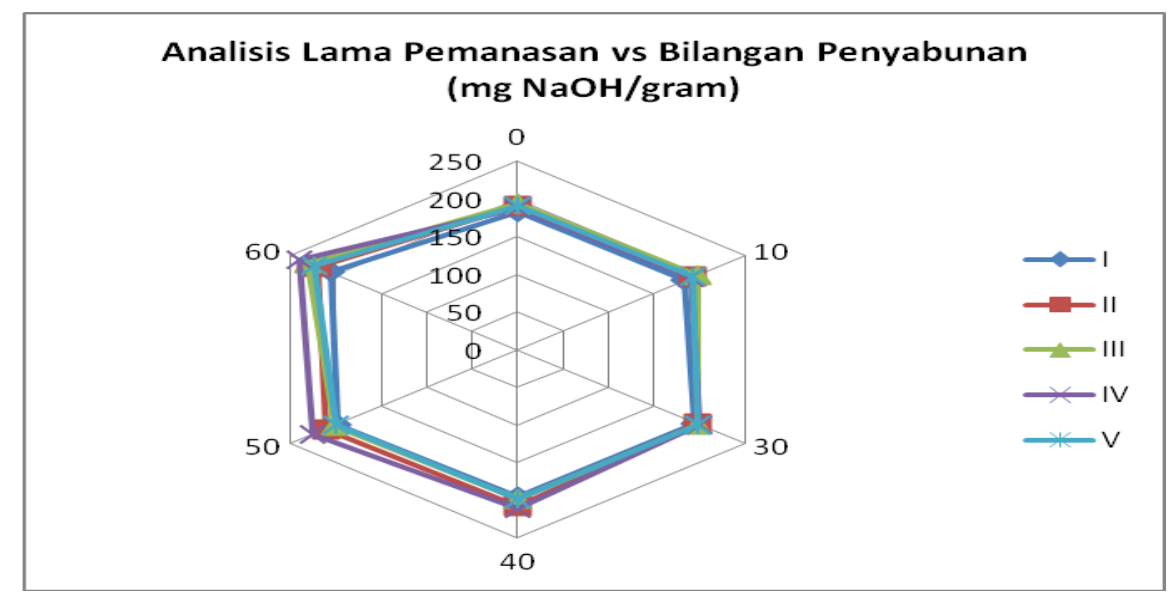

Gambar 3. Diagram Hubungan Lama Pemanasan dengan Bilangan Penyabunan.

yang ditetapkan oleh SNI $7431: 2015$ yaitu 180 - 265 mg. Namun jika dilihat dari parameter lama pemanasan dari pada setiap sampel mengalami kenaikan. Hal ini menunjukkan bahwa pemanasan yang lama akan meningkatan jumlah asam lemak tak jenuh pada minyak goreng. hal ini disebabkan karena pada suatu ikatan minyak terdapat ikatan asam lemak. Ikatan ini, jika dipanaskan dengan jangka waktu lama dapat mengakibatkan rusaknya ikatan asam lemak tersebut. Pada proses penyabunan, kerusakan ikatan pada asam lemak tersebut akan diperbaiki dengan masuknya beberapa atom dari $\mathrm{NaOH}$ kedalam ikatan tersebut. Dengan demikian waktu pemanasan yang sebentar membuat ikatan asam lemak dalam minyak goreng curah belum rusak, jadi $\mathrm{NaOH}$ yang masuk dalam ikatan hanya sedikit. Jumlah $\mathrm{NaOH}$ yang ditambahkan untuk berikatan dengan asam lemak jenuh pada sampel harus berlebih. $\mathrm{NaOH}$ yang menggantikan ikatan yang rusak dapat kita ketahui jumlahnya, maka jumlah asam lemak jenuh yang terbentuk sampel dapat kita ketahui juga. Untuk mengetahui jumlah $\mathrm{NaOH}$ yang berikatan dengan asam lemak jenuh, maka kelebihan $\mathrm{NaOH}$ yang ditambahkan untuk bereaksi dengan sampel harus kita hitung dengan cara merekasikan dengan asam yaitu $\mathrm{HCl}$ melalui proses titrasi penetralan. Proses penambahan $\mathrm{HCl}$ harus dihentikan. Jika terjadi perubahan warna dari merah menjajdi tidak berwarna. Perubahan 
warna ini merupakan sinyal dari indikator phenolphetalin, Jika berada pada suasana basa akan berwarna merah dan jika berada pada suasana asam akan tidak berwarna.

Minyak goreng yang mengandung komponen yang tidak tersabunkan seperti sterol mempunyai bilangan penyabunan rendah namun untuk minyak goreng yang mengandung asam lemak tidak jenuh tidak mempunyai bilangan penyabunan yang tinggi. Tingginya bilangan penyabunan ini disebabkan ikatan tidak jenuh dapat teroksidasi menghasilkan pembentukan gugus karbonil yang pada akhirnya dapat juga bereaksi dengan alkali (Harun, 2006).

Hasil analisis data penelitian ini yang tersaji pada diagram batang (gb. 3) menunjukkan sampel minyak yang dipanaskan pada rentang 0-60 menit dalam penelitian ini, dikatakan baik jika tidak mengalami kenaikan bilangan asam lemak jenuh yang tinggi. Namun jika pada lama pemanasan 30 menit terjadi kenaikkan jumlah asam lemak jenuh yang tinggi maka dapat disimpulkan minyak memiliki kualitas yang jelek. Hal ini dikarenakan pada lama pemanasan selama 30 menit merupakan titik parameter suatu minyak memiliki kualitas tinggi atau rendah.

Hasil analisa bilangan penyabunan sampel minyak goreng curah tidak ada yang melebihi batas syarat standar yang ditetapkan. Seluruh sampel minyak goreng curah mempunyai angka bilangan penyabunan yang baik walaupun mengalami pemanasan selama 60 menit. Dari hasil penelitian bilangan penyabunan terendah ditunjukan dengan angka bilangan penyabunan sebesar 189,05 mg NaOH/gram pada sampel IV sebagai sampel blanko. Hasil analisa hubungan lama pemanasan dengan bilangan penyabunan pada setiap lama pemanasan dari sampel (gb. 2), menunjukkan bahwa bilangan penyabunan sampel pada tiap lama pemanasan mengalami peningkatan. Peningkatan pada lama pemanasan 60 menit tingkat kenaikan tinggi. Namun masih berada dibawah standar yang ditetapkan.

Hasil analisa dari diagram jaring labalaba (gb. 3) menunjukkan bahwa bilangan penyabunan pada pemasan 030 menit dari seluruh sampel menunjukkan hasil yang tidak berbeda bermakna. Hal ini dapat diartikan tiap sampel minyak goreng curah mempunyai suatu ikatan asam lemak 
tidak jenuh dengan jumlah yang sama sehingga setelah minyak goreng curah tersebut mendapat perlakuan pemanasan pada rentang tersebut menunjukkan kualitas yang sama. Bilangan penyabunan sampel II-IV setelah dipanaskan selama 40-60, mengalami kenaikkan yang cukup tinggi jika dibandingkan dengan sampel 1 dan 5. Hal ini dapat disebbkan karena kualitas minyak yang berbeda. Dengan demikian kualitas minyak sampel I dan $\mathrm{V}$ lebih baik dibandingkan dengan sampel II-IV.

Adanya Bilangan penyabunan menunjukkan adanya proses kerusakan pada sampel, yang ditandai dengan munculnya warna coklat. Semakin tinggi bilangan penyabunan akan sebanding dengan tingkat kerusakan minyak. Begitu pula dengan warna coklat yang terbentuk. Terbentuknya warna kecoklatan disebabkan oleh pemanassan yang lama menakibatkan minyak goreng curah mengalami oksidasi dan cracking,

Hasil penelitian setelah pemasanan selama 30-60 menit sampel mengalami warna coklat. Namun sampel IV memiliki warna yang lebih tua dibandingkan dengan sampel yang lain. Dengan demikian kualitas sampel IV lebih rendah dibandingkan dengan sampel yang lainnya.

tidak menggoreng terlalu lama dengan minyak. Jika minyak goreng sudah berwana kecoklatan dan mendekati ke warna hitam. Alangkah baiknya untuk tidak digunakan lagi dan menggantinya dengan minyak goreng yang baru. Minyak yang telah rusak jika digunakan akan berakibat buruk bagi kesehatan dan bahkan dapat meminbulkan kematian.

\section{KESIMPULAN}

Hasil penelitian hubungan lama pemanasan dengan kualitas minyak, dapat disimpulkan bahwa semakin lama minyak dipanaskan, maka akan semakin besar tingkat kerusakan dari minyak tersebut.

\section{SARAN}

1. Perlu dilakukan penelitian lanjutan, dengan memperpanjang waktu lama pemanasan lebih lama 2-5 jam dan pemanasan berulang.

2. Perlu dilakukan pengujian dengan media bahan lainnya seperti mentega/margarin. 


\section{DAFTAR PUSTAKA}

Organoleptik Tempe pada

Pengulangan. Jurnal Pangan Gizi vol. 01.

Anonim. 2010. Gizi dan Kesehatan Masyarakat. Rajawali press. Jakarta.

Badan Standarisasi Nasional. SNI-35551998. Cara Uji Minyak dan Lemak. Badan Standarisasi Nasional.Jakarta.

Badan Standarisasi Nasional. SNI-37412013. Standarisasi Mutu Minyak Goreng.Badan Standarisasi Nasional. Jakarta

Fessenden, R. J dan Fessenden J. 1994. Kimia Organik Edisi Ketiga. Erlangga. Jakarta.

Gandjar, G. H dan Rohman, A. 2007. Kimia Farmasi Analisis. Pustaka Pelajar.Yogyakarta.Graha,

HAM, Mulyono. 2006. Membuat Reagen Kimia di Labotarium. PT. Bumi Aksara.Jakarta

Kataren, S. 1986. Pengantar Teknologi Minyak dan Lemak Pangan. UI Press. Jakarta

Muchtadi, Dedi. 2009. Pengantar Ilmu Gizi. Bandung: Penerbit Alfa Beta. Cit Putri, S. Islamia Dhahono. 2015. Efek Lama Pemanasa Terhadap Perubahan

Pudjatmaka, A. Hadyana. 2002. Kamus Kimia. Jakarta: Balai Pustaka
Standar Nasional Indonesia. 1995. Bahan Tambahan Makanan. Badan Standarisasi Nasional. Jakarta.

Standar Nasional Indonesia. 2008. Perlengkapan Makanan dan Minuman. Badan Standarisasi Nasional. Jakarta

Standar Nasional Indonesia. 2013. Minyak Goreng. Badan Standarisasi Nasional.Jakarta

Standar Nasional Indonesia. 2015. Mutu dan Metode Uji Minyak Nabati Murni untuk Bahan Bakar Diesel Putaran Sedang. Badan Standarisasi Nasional

Widayat, Suherman dan K, Haryani. 2006. Optimasi Proses Adsorbsi Minyak Goreng Bekas Dengan Adsorbent Zeloit Alam : Studi Pengurangan Bilangan Asam. Jurnal. Fakultas Teknik. Universitas Diponegoro Semarang. Winarno, F. G. 1995. Enzim Pangan. Jakarta: Gramedia Pustaka Winarno, F. G. 1984. Kimia Pangan dan Gizi. Jakarta: Gramedia Pustaka

Winarno, F. G. 1991. Kimia Pangan dan Gizi. Jakarta: Gramedia Pustaka

Winarno, F. G. 1999. Minyak Goreng dalam Menu Masyarakat. Jakarta: Gramedia Pustaka

Winarno, F. G. 2004. Kimia Pangan

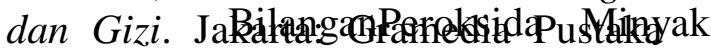
Winarno, F. G. 2008. Kimia Pangan dan Gizi Edisi Baru. Jakarta: Gramedia Pustaka 